CARMO, M.G.F.; MACAGNAN, D.; CARVALHO, A.D. Progresso da mancha-bacteriana do pimentão a partir de diferentes níveis iniciais de inóculo e do emprego ou não do controle com oxicloreto de cobre. Horticultura Brasileira, Brasília, v. 19, n. 3, p. 210-215, novembro 2.001.

\title{
Progresso da mancha-bacteriana do pimentão a partir de diferentes níveis iniciais de inóculo e do emprego ou não do controle com oxicloreto de cobre.
}

\author{
Margarida Goréte Ferreira Carmo $^{1}$; Dirceu Macagnan ${ }^{2}$; Aldir Oliveira Carvalho ${ }^{1}$ \\ ${ }^{1}$ UFRRJ, 23.851-970 Seropédica, RJ; Email: gorete@ufrrj.br; ${ }^{2} \mathrm{UFV}, 36.570-000$ Viçosa - MG
}

\section{RESUMO}

O presente trabalho teve como objetivo avaliar o progresso da mancha-bacteriana do pimentão a partir de quatro quantidades iniciais de mudas infectadas $(0 ; 3,3 ; 10$ e $100 \%)$ associado à aplicação semanal de oxicloreto de cobre ( $2,4 \mathrm{~g}$ de i.a./L de água) ou não. Foram conduzidos cinco ensaios, em condições de campo, em Seropédica (RJ), entre junho de 1996 e setembro de 1999. Quantificou-se a intensidade de doença, regularmente, por meio de estimativas visuais da severidade da doença (área foliar lesionada e desfolha) e calculou-se a área abaixo da curva de progresso da doença normalizada (AACPD/ número de dias). Estas foram submetidas à Análise de Variância $(\mathrm{p}=0,01)$ e à análise de regressão linear em função do logaritmo da quantidade inicial de mudas infectadas. A redução do inóculo inicial teve efeito direto na quantidade final de doença, e de forma mais marcante sob condições mais propícias ao desenvolvimento da doença. A eficiência do oxicloreto de cobre foi variável e na maioria das vezes ineficiente, principalmente nos períodos mais propícios a epidemia, com redução de sua eficiência pela elevação da temperatura.

Palavras-chaves: Capsicum annuum, Xanthomonas campestris $p v$ vesicatoria, epidemiologia, controle químico.

\begin{abstract}
Progress of bacterial leaf spot of pepper starting with different initial quantities of infected seedlings and treatment with the use or not of copper oxichloride.

The progress of pepper leaf spot was examined starting with different initial quantities of infected seedlings $(0 ; 3.3 ; 10$; and 100\%), treated or not with chemical control through the weekly application of copper oxichloride ( $2.4 \mathrm{~g}$ of i.a/L of water). Five experiments were undertaken in Seropédica (Rio de Janeiro, Brazil) in different time periods from June, 1996 to September, 1999. The intensity of disease was quantified regularly through visual estimation of disease severity (leaf area with lesions and leaf loss). The values for the area under the disease progress curves were calculated (AUDPC/number of days). The data was subjected to analysis of variance $(\mathrm{p}<0,01)$ and simple linear regression analysis was employed for the values of AUDPC/day in function of the initial quantity of infected seedlings. The reduction of initial inoculation had a direct affect on the final severity of disease, which was more stricking under the most favorable conditions for disease development. The efficiency of copper fungicides was variable. In the majority of cases, copper fungicides were not efficient, especially during the periods most favorable to the epidemics. As temperatures became higher, reduced efficiency was observed.
\end{abstract}

Keywords: Capsicum annuum, Xanthomonas campestris $p v$. vesicatoria, epidemiology, chemical control.

(Aceito para publicação em 5 de outubro de 2.001)

$\mathrm{O}$ pimentão é uma das dez hortaliças mais importantes economicamente no Brasil, com especial destaque para o Estado do Rio de Janeiro. Pode apresentar altas produtividades (Cobbe, 1983), muitas vezes, no entanto, reduzida pela ocorrência de várias doenças, particularmente as bacterioses. Dentre estas destaca-se a pústula ou manchabacteriana, causada por Xanthomonas campestris pv. vesicatoria (Doidge) Dye (Kimura \& Carmo, 1996). Esta foi reclassificada recentemente, em duas novas espécies: Xanthomonas vesicatoria e Xanthomonas axonopodis pv. vesicatoria (Jones et al., 1998).

A doença afeta todos os órgãos aéreos das plantas e ocorre em qualquer estádio de desenvolvimento do pimentão, sendo mais prejudicial às mudas, em fase de viveiro, e às folhas e frutos de plantas adultas. Em períodos chuvosos, as infecções são mais abundantes e as lesões se desenvolvem mais rapidamente em número e tamanho, levando à desfolha intensa da planta (Carmo et al., 1996b).

A incidência da doença em campos de cultura de pimentão é relacionada diretamente à umidade, temperatura (22 a $32^{\circ} \mathrm{C}$ ), precipitação e variedade cultivada (Shekhawat \& Chakhavarti, 1976; Kimura \& Carmo, 1996). Pode causar sérios prejuízos à lavoura sob condições de chuvas prolongadas ou de irrigação por aspersão, principalmente quando acompanhadas de rajadas de ventos, que promovem sua rápida disseminação na cultura (Hayward \& Waterston, 1964;
Pohronezny et al., 1992). Pelos resultados recentes de um estudo da epidemiologia da doença em viveiro, observa-se que a baixa incidência inicial de plântulas infectadas, em condições de ambiente com temperatura moderada e alta precipitação pode gerar epidemias severas da doença, com até $100 \%$ de mudas infectadas, enquanto que sob ambiente frio e seco os danos são bem menores (Carmo et al., 1996a).

No campo, após início da epidemia, normalmente é recomendada a aplicação de fungicidas cúpricos ou cuprorgânicos que, em geral, não diferem entre si (Aguiar, 1997; Marco \& Stall, 1983) exceto quando da ocorrência de estirpes resistentes ao cobre, onde o segundo pode apresentar maior eficiên- 
cia (Marco \& Stall, 1983) ou não (Aguiar, 1997; Jones et al., 1991). Aguiar et al. (2000) relatam a ocorrência no Brasil de estirpes resistentes a até $1800 \mathrm{ml} / \mathrm{ml}$ de cobre. O controle químico é, ainda, dificultado pela ocorrência alta e freqüente de estirpes resistentes ao sulfato de estreptomicina (Stall \& Thayer, 1962; Jones et al., 1991; Ward \& O'Garro, 1992).

O presente trabalho teve como objetivo estudar, em condições de campo, em ambientes distintos, o desenvolvimento da mancha-bacteriana do pimentão a partir de diferentes quantidades iniciais de mudas infectadas por $X$. campestris pv. vesicatoria, associado ao controle químico com fungicida à base de cobre.

\section{MATERIAL E MÉTODOS}

Para estudar o progresso da manchabacteriana do pimentão e a eficiência da aplicação de fungicidas cúpricos e da redução do inóculo inicial no controle da doença foram conduzidos cinco ensaios de campo em diferentes épocas do ano. O primeiro e o segundo ensaios foram realizados no campo experimental da Área de Fitopatologia da Universidade Federal Rural do Rio de Janeiro no período de junho a setembro de 1996 e de novembro de 1997 a fevereiro de 1998, respectivamente. O terceiro, quarto e quinto ensaios foram realizados no Campo Experimental do Departamento de Fitotecnia nos períodos de março a agosto de 1998, de novembro de 1998 a janeiro de 1999 e de maio a setembro de 1999, respectivamente.

Em todos os cinco ensaios, as mudas foram produzidas em bandejas de isopor, preenchidas com substrato preparado a partir de solo argiloso adicionado à matéria orgânica de origem vegetal e animal. As sementes utilizadas foram previamente secas e, em seguida, tratadas termicamente, utilizando calor via seco, sob ventilação, a $70^{\circ} \mathrm{C}$ por 96 horas (Azevedo et al., 1991). As cultivares utilizadas foram 'Agronômico 10G', nos primeiros quatro ensaios e 'Cascadura Ikeda' no quinto ensaio. No semeio foram colocadas três sementes por célula seguido de desbaste e repicagens para obtenção de uma muda por célula.
Nos cinco ensaios, as mudas de uma bandeja foram previamente inoculadas para a formação das fontes de inóculo da doença. Utilizou-se como inóculo culturas puras do isolado ENA 4464 de $X$. campestris pv. vesicatoria, reisolados de plantas de pimentão, com 36 a 48 horas de crescimento a $28 \pm 2{ }^{\circ} \mathrm{C}$, em meio de DYGS (Rodrigues Neto et al., 1986). A inoculação foi efetuada pela atomização de suspensão bacteriana, contendo cerca de $10^{8}$ u.f.c. $/ \mathrm{ml}$, nas faces dorsal e ventral das folhas, até o ponto de escorrimento, por meio de atomizador manual. Após a inoculação, as mudas foram mantidas em ambiente de alta umidade, fornecida por microaspersão intermitente por 48 horas, e isoladas das demais até a transferência para as respectivas parcelas.

Para cada ensaio utilizou-se uma área diferente, previamente preparada e adubada conforme recomendações da análise de solo e do Manual de Adubação para o Estado do Rio de Janeiro (De Polli et al., 1988).

Em todos os cinco ensaios a área experimental foi dividida em 24 parcelas de $15 \mathrm{~m}^{2}$, com um total de $600 \mathrm{~m}^{2}$ de área útil. Para minimizar as interferências entre as parcelas estas foram circundadas por quatro fileiras de milho, plantado no espaçamento de $0,90 \times 0,20$ m, 30 a 40 dias antes do transplante do pimentão. Cada parcela continha 30 plantas, espaçadas de 1,0x0,5 m, distribuídas em três fileiras com 10 plantas. Avaliaram-se quatro quantidades iniciais de mudas contaminadas $(0 ; 3,3 ; 10$ e $100 \%$ ) e a aplicação semanal ou não de oxicloreto de cobre, $2,4 \mathrm{~g}$ ia/L (recomendação do fabricante), totalizando oito tratamentos arranjados em esquema fatorial 4 (proporções de mudas infectadas) x 2 (com ou sem aplicação semanal de oxicloreto de cobre), com três repetições.

Por ocasião do transplante, 30 a 40 dias após a emergência de acordo com a época do ano, foram também plantadas, ao acaso em cada parcela, as mudas infectadas por $X$. campestris pv. vesicatoria, em proporções suficiente para se obterem as diferentes quantidades iniciais de mudas doentes de cada tratamento.

Com o aparecimento dos primeiros sintomas, nas plantas vizinhas às plan- tas inoculadas, iniciaram-se as avaliações da severidade da doença e o mapeamento das plantas com sintomas visíveis. As avaliações foram efetuadas a cada cinco $(+2)$ dias, até o final do ensaio, por cerca de dois meses para os ensaios realizados no período de verão e de três meses para ensaios realizados no período de inverno. Foram avaliadas oito plantas situadas na fileira central, por parcela, tomando-se a planta inteira. A severidade ou área foliar lesionada foi estimada com auxílio da escala de Horsfall \& Barrat (1945), modificada, onde 0) sem sintomas; 1) 1,1 a $3 \%$ de área foliar lesionada; 3) 3,1 a 6\%; 4) 6,1 a $12 \%$; 5) 12,1 a $25 \%$; 6) 25,1 a $50 \%$; 7) 50,1 a $75 \%$ e 8 ) mais que $75 \%$.

As irrigações foram efetuadas conforme a necessidade em função da época do ano e da incidência de chuvas. Utilizou-se o sistema por aspersão tendo-se o cuidado de uniformizar o volume e a intensidade de água distribuído nas diferentes parcelas em cada irrigação. As adubações de cobertura foram efetuadas por ocasião do florescimento, e a cada três semanas até o final do ensaio. Demais tratos culturais comuns à cultura do pimentão como controle de insetos, ácaros, assim como o tutoramento das plantas foram efetuados conforme as necessidades e as recomendações usuais para a cultura no Estado.

Paralelamente à realização dos ensaios, foram coletados os dados meteorológicos fornecidos pela Estação Meteorológica da Estação Experimental de Itaguaí, da Empresa de Pesquisa Agropecuária do Estado do Rio de Janeiro (PESAGRO-RIO), situada a cerca de $1.000 \mathrm{~m}$ da área experimental. Destes, tomaram-se os dados diários de temperatura máxima, temperatura mínima, temperatura média, total de precipitação em mm, duração da chuva em horas e umidade relativa média do ar.

Com os dados de severidade em cada avaliação calcularam-se, para cada parcela, os valores da Área Abaixo da Curva de Progresso da Doença (AACPD) (Shanner \& Finney, 1977). Esses valores foram então normalizados, para os cinco ensaios, pela subdivisão pelo número total de dias entre a primeira e última avaliação da severidade, o que foi distinto entre os ensaios. 

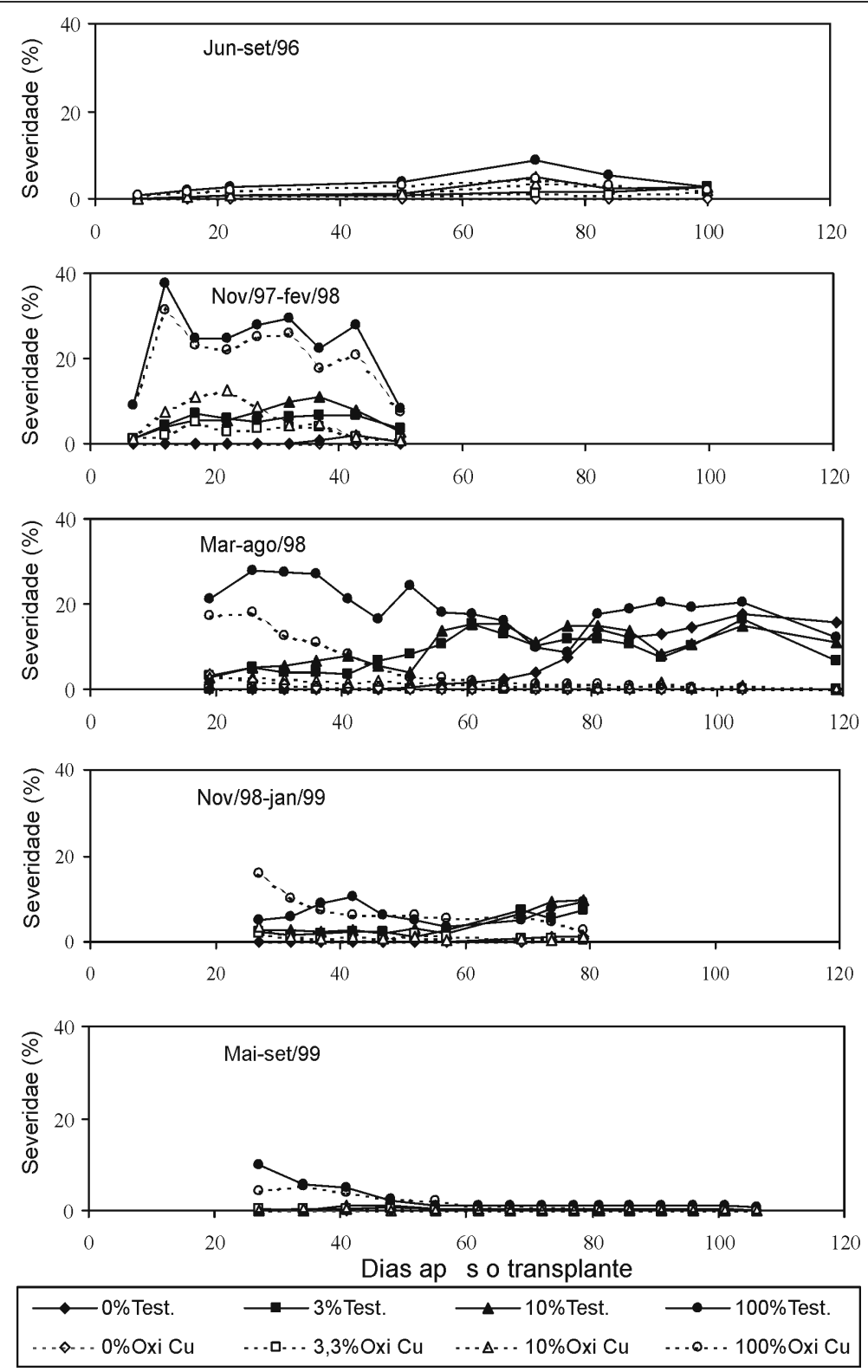

Figura 1. Curvas de progresso da mancha-bacteriana do pimentão a partir de quatro quantidades iniciais de mudas infectadas $(0 ; 3,3 ; 10$ e 100\%) e da aplicação semanal de oxicloreto de cobre (OxiCu) ou não (Test.), em cinco épocas distintas. Seropédica, UFRRJ, 1996-99.

Os valores de AACPD normalizados (AACPD/dia) foram submetidos à Análise de Variância onde testou-se a significância do efeito da incidência inicial de mudas contaminadas, do controle químico e da interação entre estes. As médias de AACPD/dia para as parcelas que receberam ou não pulverizações com oxicloreto de cobre foram comparadas pelo próprio teste $\mathrm{F}$. O efeito da redução do inóculo inicial sobre o desenvolvimento da epidemia foi analisado por meio de regressão linear simples dos valores de AACPD/dia em função das diferentes quantidades iniciais de mudas conta- minadas. Efetuou-se, ainda, análise de correlação entre os dados meteorológicos e a variação na intensidade de doença ao longo de cada ensaio. Para tanto, tomaram-se os valores médios dos dados de temperatura (máxima, média e mínima), de precipitação (duração e intensidade) e da umidade relativa do ar, registrados nos cinco dias anteriores à avaliação, e a intensidade de doença, dada pelo valor de AACPD calculado entre as duas avaliações referidas, cinco dias em média, para cada um dos oito tratamentos. Adotou-se como correlação significativa aquelas que apresentassem coeficientes maior que 0,60 ou menor que $-0,60$ e significância até $5,0 \%$ de probabilidade.

A fim de se avaliar a presença de isolados de X. campestris pv. vesicatoria resistentes ao íon cobre foram amostradas folhas infectadas nas parcelas pulverizadas ou não, ao final de três dos cinco ensaios: novembro de 1997 a fevereiro de 1998, maio a agosto de 1998 e novembro de 1998 a janeiro de 1999. Os isolados da bactéria obtidos foram submetidos a testes de resistência ao íon cobre e comparados com dois padrões, um sabidamente sensível (ENA-818) e outros dois resistentes: (E3LC) (Aguiar, 1997) e outro selecionado após cultivo sucessivo em meio contendo doses crescentes de cobre. Todos os isolados a serem testados foram preservados em solução salina $(0,85 \%$ de $\mathrm{NaCl})$ até a realização dos testes de sensibilidade. Os testes foram feitos segundo a metodologia utilizada por Aguiar et al. (2000) e Marco \& Stall (1983). Para tanto, para cada um dos isolados a serem testados, tomaram-se alíquotas de $50 \mu \mathrm{l}$ de uma suspensão contendo $10^{7} \mathrm{ufc} / \mathrm{ml}$ que foram adicionadas a $1 \mathrm{ml}$ de solução contendo o íon cobre em concentração conhecida $(1800 ; 900 ; 450 ; 225 ; 112,5 ; 56 ; 28 ; 14$; $7 ; 3,5$ e $0,0 \mu \mathrm{g} / \mathrm{ml}$ de cobre) e incubadas por duas horas. Da suspensão original e de mais quatro diluições (série 1:10) tomaram-se alíquotas de $100 \mu \mathrm{g} / \mathrm{L}$ que foram riscadas em três placas de Petri contendo o meio de Dygs (Rodrigues Neto et al., 1986).

\section{RESULTADOS E DISCUSSÃO}

Os sintomas iniciais nas plantas não inoculadas apareceram aos 7; 7; 13; 27 e 10 dias após o transplante, respectivamente, nos ensaios realizados em junho a setembro de 1996, novembro de 1997 a fevereiro de 1998, março a agosto de 1998, novembro de 1998 a janeiro de 1999 e maio a setembro de 1999.

Constatou-se efeito significativo $(p<0,01)$ da quantidade inicial de mudas infectadas, em todos os cinco ensaios, e do controle químico em apenas dois ensaios. Não houve interação significativa entre a quantidade inicial de inóculo e a eficiência do controle químico em nenhum dos cinco ensaios. 
Tabela 1. Área abaixo da curva de progresso da mancha-bacteriana do pimentão normalizada (AACPD/dia), para os tratamentos com aplicação semanal de oxicloreto de cobre (2,4 g i.a./L) e testemunha sem aplicação, em cinco épocas distintas. Seropédica, UFRRJ, $1996-99$.

\begin{tabular}{|c|c|c|c|c|c|c|}
\hline \multirow{2}{*}{ Tratamento } & \multicolumn{6}{|c|}{ AACPD/dia } \\
\hline & Jun-set/96 & Nov/97-fev/98 & Mar-ag & /98 & Nov/98-jan/99 & Mai-set/99 \\
\hline Testemunha & $0,61 \mathrm{a}$ & $9,53 \mathrm{a}$ & 11,55 & & $3,59 \mathrm{a}$ & $0,72 \mathrm{a}$ \\
\hline Oxicloreto de cobre & $0,40 a$ & $8,97 a$ & 1,48 & $b$ & $2,11 \quad b$ & $0,47 a$ \\
\hline CV \% & 32,71 & 35,10 & 36,60 & & 38,80 & 35,19 \\
\hline
\end{tabular}

Médias seguidas pela mesma letra na coluna não diferem estatisticamente pelo teste de $\mathrm{F}$ a 1,0\% de probabilidade.

Nos ensaios realizados em julho-setembro de 1996 e julho-setembro de 1999 registrou-se menor desenvolvimento da doença (Figuras 1 e 2). Nesses períodos foram registrados os menores valores de temperatura e de precipitação (Figura 3) considerados desfavoráveis ao progresso da mancha bacteriana (Carmo et al., 1996). Nestes ensaios não houve diferença significativa entre as parcelas pulverizadas e não pulverizadas com oxicloreto de cobre, revelada pelas curvas de progresso e valores de AACPD/dia (Figuras 1 e 3; Tabela 1). No ensaio realizado no período de novembro de 1997 a fevereiro de 1998, caracterizado pela maior taxa de precipitação e temperaturas mais elevadas (Figura 3), observou-se rápido progresso e maior intensidade da doença, com extensa área foliar lesionada e intensa desfolha, reduzindo o período produtivo da cultura (Figura 1). Neste mesmo período não houve efeito significativo das pulverizações com oxicloreto de cobre, que pode ser constatado nas curvas de progresso, semelhantes para as respectivas parcelas com igual quantidade inicial de mudas infectadas, pulverizadas ou não (Figura 1) e pelos valores de AACPD/dia calculados (Figura 3; Tabela 1). No ensaio realizado no período de março a agosto de 1998, caracterizado por temperaturas mais baixas e baixa taxa de precipitação (Figura 3) também registraram-se valores elevados de severidade da mancha-bacteriana, mas apenas nas parcelas não submetidas ao controle quími$\mathrm{co}$, que se mostrou altamente eficiente com redução do progresso da doença (Figura 1) e consequentemente dos valores de AACPD/dia (Figura 3; Tabela 1). Pela Figura 1, pode-se observar a queda gradativa na severidade da mancha-bacteriana na parcela com $100 \%$ de mudas infectadas e pulverizadas sema-

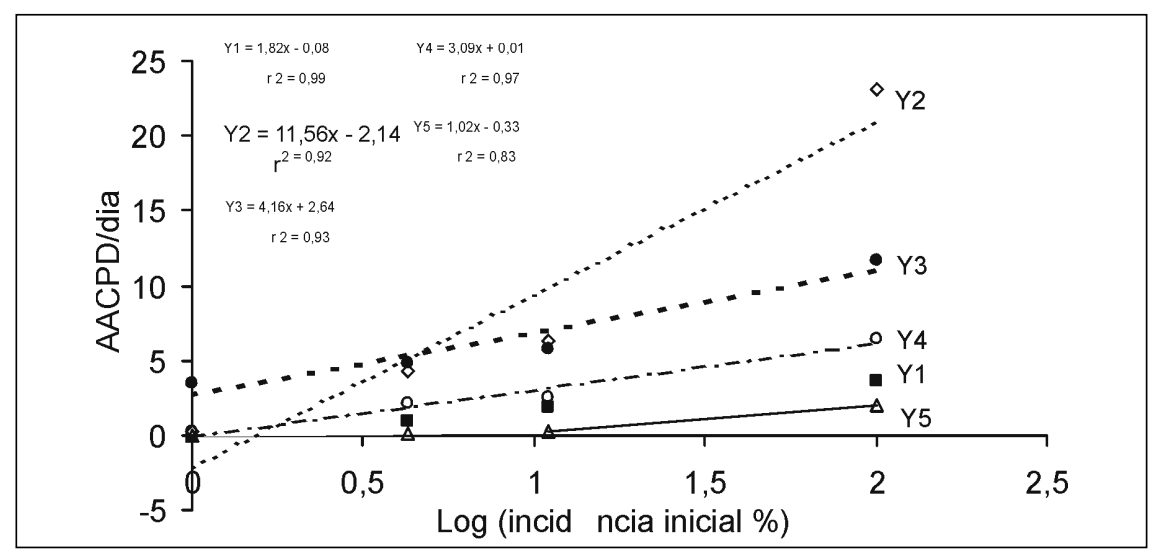

Figura 2. Valores médios de AACPD/dia, considerando as parcelas pulverizadas e não pulverizadas, em função do logarítimo da quantidade inicial de mudas de pimentão infectadas por Xanthomonas campestris pv. vesicatoria, em cinco ensaios realizados nos períodos de jun-set de 96 (Y1), nov/97 a fev/98 (Y2) mar-ago/98 (Y3), nov/98 a jan/99 (Y4) e mai-set/99 (Y5), estimados por meio de análise de regressão linear simples. Seropédica, UFRRJ, 1996-99.

nalmente com oxicloreto de cobre, terminando com valores próximos de zero, a exemplo das demais parcelas com 10; 3,3 e $0 \%$ de mudas infectadas. Já no quarto ensaio, novembro de 1998 a janeiro de 1999, mesmo sob alta taxa de precipitação mas temperaturas mais amenas (Figura 3) observou-se pequeno desenvolvimento da doença, e diferença significativa $(p<0,05)$ entre as parcelas pulverizadas e as não pulverizadas com oxicloreto de cobre, porém com diferenças menos acentuadas comparadas ao ensaio anterior (Figuras 1 e 3 e Tabela 1). Maringoni et al. (1986) também não encontraram constância na eficiência do controle da mancha-bacteriana do tomateiro com diferentes produtos, antibióticos e cúpricos, em ensaios realizados em duas épocas distintas.

Dentro de cada ensaio, constataramse correlações significativas entre a variação na severidade da manchabacteriana e as variáveis climáticas, principalmente temperatura. Porém, com variações entre os tratamentos e muitas vezes sem um padrão definido. A interferência das condições climáti- cas sobre o desenvolvimento da doença pode ser melhor percebida pela observação dos cinco ensaios, apresentados na Figura 3. Nas parcelas pulverizadas as variações na severidade da doença observadas entre os diferentes períodos foi menor, exceto no ensaio realizado no período de novembro de 1997 a fevereiro de 98 quando foram registrados altos valores de AACPD/dia, e aparentemente respondeu de forma mais acentuada às variações climáticas. Este resultado provavelmente se deve ao efeito das condições climáticas sobre a eficiência do tratamento com fungicidas cúpricos no controle da manchabacteriana. Com a elevação da temperatura ocorreu um aumento da frequiência das irrigações com aumento consequiente da lavagem dos fungicidas aplicados, a exemplo do que ocorre com as precipitações, acentuando mais as diferenças entre os períodos frio e seco em relação aos mais quentes e úmidos, nas parcelas pulverizadas. No presente trabalho, a aplicação semanal de oxicloreto de cobre somente foi significativamente superior à testemunha $(\mathrm{p}<0,01)$ em 

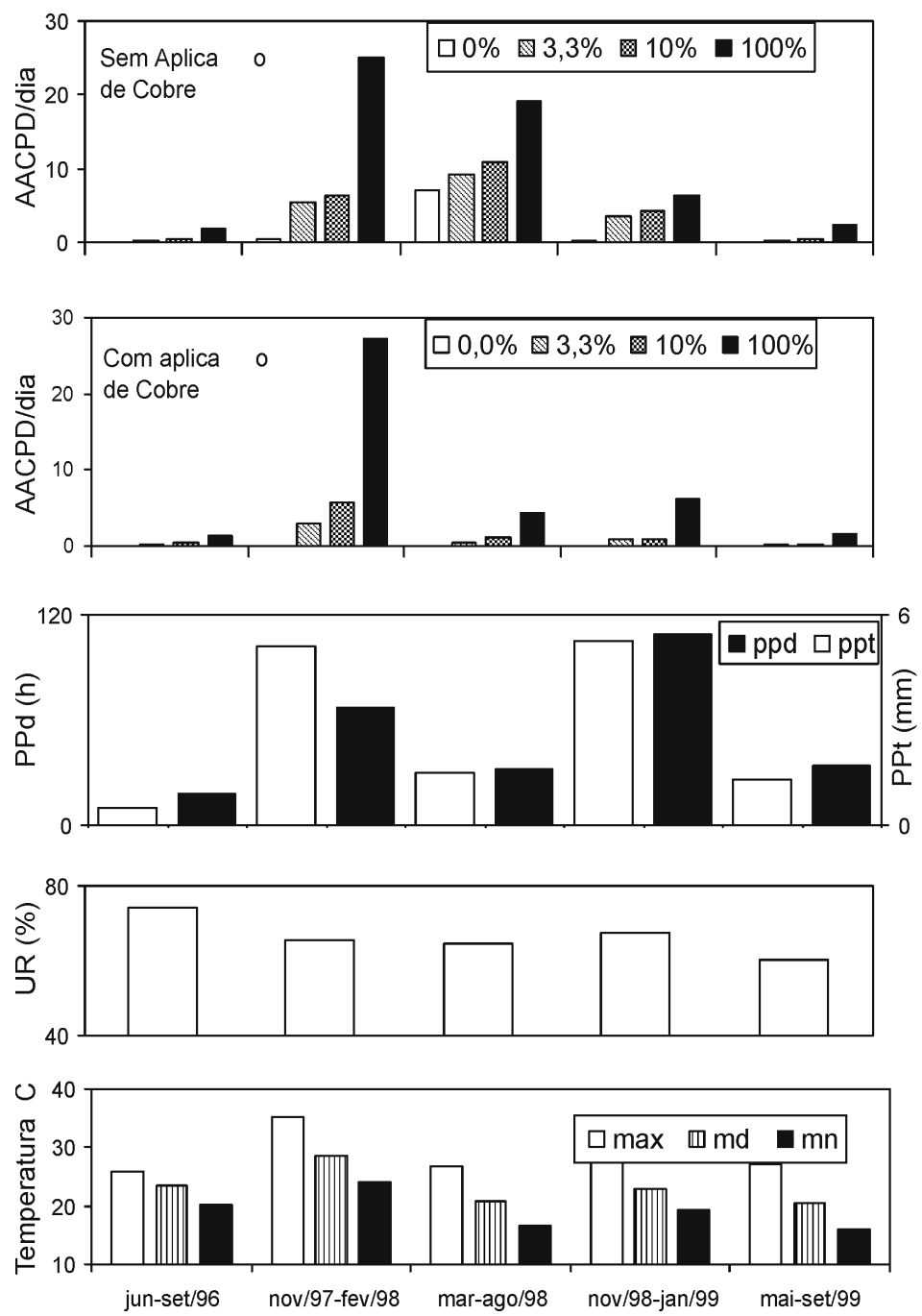

Figura 3. Valores médios de AACPD/dia da mancha-bacteriana do pimentão para tratamentos com diferentes níveis iniciais de mudas infectadas $(0 ; 3,3 ; 10$ e $100 \%)$, pulverizadas semanalmente, ou não, com oxicloreto de cobre $(2,4 \mathrm{~g}$ i.a/l) , em cinco épocas distintas, umidade relativa (\%), precipitação total (PPt) e duração (PPd) e médias de temperatura (máxima, média, mínima), nos respectivos períodos. Seropédica, UFRRJ, 1996-99.

dois dos cinco ensaios, março a agosto de 1998 e novembro de 1998 a janeiro de 1999 (Tabela 1), caracterizados pela baixa e alta precipitação, respectivamente, e temperaturas moderadas $(16,5$ a $26,6^{\circ} \mathrm{C}$ e 19,2 a $\left.27,6^{\circ} \mathrm{C}\right)$.

O progresso de doenças bacterianas de parte aérea apresenta algumas particularidades distintas em relação a doenças fúngicas. A bactéria pode se desenvolver como residente em folhas de plantas hospedeiras (Hirano \& Upper, 1983) e se multiplicar sob condições de baixa umidade ou ambiente desfavorável, sem causar sintomas aparentes da doença e as epidemias vindo a ocorrer quando as condições do ambiente tornam-se favoráveis (Bashan et al., 1982).
Pernezny \& Collins (1997) afirmam que áreas protegidas como gemas e flores funcionam como reservatórios de inóculo por protegerem as células bacterianas de altos níveis de luz ultravioleta e apresentarem ambiente mais úmido, garantindo sua multiplicação e, principalmente, por protegê-las de doses letais dos bactericidas aplicados. Desta forma, quantidades suficientes de células escapam e atuam como constante reservatório de inóculo, seguindo o desenvolvimento de doença, conforme a ocorrência de condições propícias. As bactérias respondem muito rapidamente às variações climáticas, principalmente umidade. Os períodos de alta umidade relativa (95-100\%) são importantes para ocorrência de infecção em faixa ampla de temperatura (22 a $32^{\circ} \mathrm{C}$ ), podendo levar à desfolha intensa da planta (Diab et al., 1982).

Outro fator freqüentemente citado como responsável pela baixa eficiência no controle com produtos à base de cobre é a ocorrência de estirpes resistentes ao produto (Marco \& Stall, 1983; Pohronezny et al., 1992; Aguiar, 1997). Não se encontrou resistência considerável ao cobre nos isolados recuperados durante o ciclo da cultura, avaliado em três dos cinco ensaios. Este resultado, porém, não é conclusivo visto os testes terem sido efetuados alguns meses após o isolamento. Durante este período foi constatada redução dos níveis de resistência naqueles isolados originalmente selecionados como padrão resistente. Em estudo da persistência da resistência a bactericidas por isolados de $X$. campestris pv. vesicatoria preservados in vitro Singh \& Chand (1994) também relatam o declínio e estabilização da resistência a níveis baixos quando preservados em meio sem o referido bactericida. Desta forma, neste tipo de ensaio o teste deve ser feito logo após o isolamento ou utilizar métodos de preservação dos isolados que garantam a manutenção da característica (resistência ou não ao cobre).

Considerando-se o efeito da redução do inóculo inicial, este foi significativo em todos os cinco ensaios (Figura 2). As regressões lineares simples dos valores da AACPD/dia em função do logaritmo da quantidade inicial de mudas infectadas foram altamente significativas ( $p<0,001)$, com elevado valor de $\mathrm{r}^{2}$, em todos os cinco ensaios. Houve um aumento linear da intensidade da doença com o aumento da quantidade de inóculo inicial, porém, com diferenças quanto à magnitude deste efeito. Este foi claramente mais marcante nos períodos mais favoráveis à doença, novembro de 1997 a fevereiro de 1998, seguido dos ensaios de março a agosto de 1998 e novembro 98 a janeiro de 1999. Em junho a setembro de 1996 e maio a setembro de 1999, caracterizados por menores temperaturas e precipitação, e conseqüente menor progresso da doença, também houve efeito significativo da redução do número inicial de mudas 
contaminadas, porém bem mais suave.

Quanto ao controle da doença no campo, constatou-se que a redução do inóculo inicial tem efeitos diretos na quantidade final de doença, com efeitos mais marcantes sob condições mais propícias ao desenvolvimento de epidemias, o que reforça a importância da utilização de mudas sadias e provenientes de sementes sadias. Quanto à eficiência do controle químico à base de fungicidas cúpricos, confirmou-se ser este bastante variável e na maioria das vezes não eficiente. As possíveis causas da não constância da eficiência do controle químico com oxicloreto de cobre podem ser devida a fatores como 1) desenvolvimento de variantes resistentes ao longo do período de pulverizações provocado pela constante lavagem do produto e exposição a subdosagens; 2) local de aplicação do produto (em cima x em baixo da folha) e conseqüente maior ou menor lavagem e 3) a própria lavagem do produto pelas chuvas ou irrigações, mais intensas exatamente nos períodos mais propícios a epidemias, quando ocorre maior disseminação do patógeno e aumento de sua multiplicação.

\section{AGRADECIMENTOS}

À FAPERJ pelo financiamento do presente projeto e ao $\mathrm{CNPq} / \mathrm{PIBIC}$ pela concessão da bolsa de iniciação científica ao segundo autor.

\section{LITERATURA CITADA}

AGUIAR, L.A. Identificação de isolados nacionais de Xanthomonas campestris pv. vesicatoria (Doidge) Dye, agente da mancha-bacteriana do pimentão (Capsicum annuum L.), resistentes ao cobre e perspectivas de seu controle com formulações cúpricas e cuprorgânicas. Seropédica: UFRRJ, 1997. 153 p. (Tese mestrado).
AGUIAR, L.A.; KIMURA, O.; CASTILHO, A.M.C.; CASTILHO, K.S.C.; RIBEIRO, R.L.D.; AKIBA, F.; CARMO, M.G. Resistência ao cobre em isolados nacionais de Xanthomonas campestris pv. vesicatoria. Agronomia, v. 34, n. 1/2, p. 7882, 2000

AZEVEDO, J.M.N.; KIMURA, O.; RIBEIRO, R.L.D.; AKIBA, F. Tratamento térmico de sementes de pimentão objetivando a erradicação de Xanthomonas campestris pv. vesicatoria. In: CONGRESSO BRASILEIRO DE FITOPATOLOGIA, 24, 1991, Rio de Janeiro. Anais... Brasília: SBF, 1991. p 44.

BASHAN, Y.; DIAB, S.; OKON, Y. Survival of Xanthomonas campestris pv. vesicatoria in pepper seeds and roots in symptomless and dry leaves in non-host plants and in the soil. Plant and Soil, v. 68, p. 161-170, 1982.

CARMO, M.G.F.; KIMURA, O.; MAFFIA, L.A.; CARVALHO, A.O. Determinação do nível de tolerância de Xanthomonas campestris pv. vesicatoria em sementes de pimentão. Fitopatologia Brasileira, Brasília, v. 21, n. 3, p. 336-341, 1996a.

CARMO, M.G.F.; KIMURA, O.; MAFFIA, L.A.; CARVAlHO, A.O. Progresso da pústula bacteriana do pimentão, causada por Xanthomonas campestris pv. vesicatoria, em condições de viveiro. Fitopatologia Brasileira, Brasília, v. 21, n. 1, p. 66-70, 1996 b.

COBBE, R.V. Reavaliando as hortaliças. Horticultura Brasileira, Brasília, v. 1, n. 3, p. 1017, 1983.

DE POLLI, H. (Coord.) Manual de Adubação para o Rio de Janeiro. Seropédica: Ed. Universidade Rural, 1988. 179 p.

DIAB, S.; BASHAN, Y.; OKON, Y. HENIS, Y. Effects of relative humidity on bacterial scab caused by Xanthomonas campestris pv. vesicatoria on pepper. Phytopathology, n. 72, p. 1257-1260, 1982.

HAYWARD, A.C.; WATERSTON, J.M. Xanthomonas vesicatoria: Descriptions of pathogenic fungi and bacteria. Kew, Surrey, England, Commonwealth Mycological Institute, 2 p. 1964.

HIRANO, S.S.; UPPER, C.D. Ecology and epidemiology of foliar bacterial pathogens. Annual Review of Phytopathology, v. 29, p. 243-269. 1983.

HORSFALL, J.G.; BARRAT, R.W. An improved grading system for measuring plant diseases. Phytopathology, v. 35, p. 577-583. 1945.

JONES, J.B.; STALL, R.E.; BOUZAR, H. Diversity among xanthomonads pathogenic on pepper and tomato. Annual Review of Phytopathology, v. 36, p. 41-58, 1998.
JONES, J.B.; WOLTZ, S.S.; JONES, J.P.; PORTIER, K.L. Population dynamics of Xanthomonas campestris pv. vesicatoria on tomato leaflets treated with copper bactericides. Phytopathology, v. 81, n. 7, p. 714-719. Jul. 1991. KIMURA, O.; CARMO, M.G.F. Doenças do pimentão causada por bactérias. Informe Agropecuário, Belo Horizonte, v. 18, n. 184, p. 66-73, 1996.

MARCO, G.M.; STALL, R.E. Control of bacterial spot of pepper initiated by Xanthomonas campestris pv. vesicatoria that differ in sensibility to copper. Plant Disease, v. 67, n. 7, p. 779-781, 1983.

MARINGONI, A.C.; KUROZAWA, C.; BARBOSA, V.; SILVA NETO, J.M. Controle químico da mancha-bacteriana (Xanthomonas campestris pv. vesicatoria (Doidge)) Dye do tomateiro (Lycopersicon esculentum Mill.). Summa Phytopathologica, v. 12, n. 1, p. 93-101, 1986.

PERNEZNY, K.; COLLINS, J. Epiphytic populations of Xanthomonas campestris pv. vesicatoria on pepper: relationships to host-plant resistance and exposure to copper sprays. Plant Disease, v. 81, n. 7, p. 791-794, 1997.

POHRONEZNY, K.; HEWITT, M.; INFANTE, J.; DATNOFF, L. Wind and wind-generated sand injury as factors in infection of pepper by Xanthomonas campestris pv. vesicatoria. Plant Disease, v. 76., n. 10, p. 1036-1039, 1992.

RODRIGUES NETO, J.; MALAVOLTA JR., V.A.; VICTOR, O. Meio simples para o isolamento e cultivo de Xanthomonas campestris pv. citri tipo B. Summa Phytopathologica, v. 12, n. 1-2. p. 16, 1986.

SHANER, G.; FINNEY, R.E. The effect of nitrogen fertilization on the expression of slowmildewing resistance in knox wheat. Phytopathology, v. 67, n. 10, p. 1051-1056, 1977. SHEKHAWAT, P.S.; CHAKHAVARTI, B.P. Factors affeting development of bacterial leaf spot of chillies caused by Xanthomonas campestris pv. vesicatoria. Indian Phytopathology, v. 29, p. 392397, 1976.

SINGH, R.; CHAND, R. Distribution of resistance to copper, zinc, and streptomycin in Xanthomonas campestris pv. vesicatoria (Doidge) Dye in India and its impact on control of bacterial spot of tomato. Journal of Plant Diseases and Protection, v. 101, n. 1, p. 80-85, 1994.

STALL, R.E.; THAYER, P.L. Streptomycin resistance of the bacterial spot pathogen and control with streptomycin. Plant Disease Report, v. 46, p. 389-389, 1962.

WARD, H.P.; O' GARRO, L.W. Bacterial spot of pepper and tomato in Barbados. Plant Disease, v. 76, n. 10, p. 1046-1048, 1992. 